Piotr Grochowski

Uniwersytet Mikołaja Kopernika w Toruniu

\title{
TUTORIALE ANTYWAMPIRYCZNE W SERWISIE YOUTUBE. MIĘDZY DYSKURSEM EKSPERCKIM A CYBERFOLKLOREM
}

\section{Wstęp}

Tradycyjne wierzenia i narracje demoniczne ulegają zwykle szybkiej destrukcji wraz ze zmianami, jakie zachodzą w obrębie ogólnych ram światopoglądowych oraz konkretnych warunków materialnej egzystencji człowieka, składających się na pierwotny kontekst ich funkcjonowania (Gaj-Piotrowski 1993: 35-37). Większość postaci i zjawisk charakterystycznych dla polskiej demonologii ludowej nie stanowi już obecnie ważnych elementów potocznego imaginarium i nie pojawia się w spontanicznych narracjach, które można by zaliczyć do współczesnego folkloru. Są one wykorzystywane jedynie jako motywy literackie, swego rodzaju atrakcje turystyczne lub swoiste znaki rozpoznawcze w konstruowanych instytucjonalnie strategiach kreowania lokalnej tożsamości i promowania poszczególnych regionów. Od tej zasady można jednak wskazać dwa istotne wyjątki. Pierwszym z nich jest zmora nocna, która ciągle stanowi obiekt wierzeń i jest bohaterem licznych narracji generowanych głównie w obrębie nieformalnej komunikacji internetowej (Grochowski 2016). Drugim zaś jest wampir, który ulegając daleko idącej transformacji, dał początek bardzo popularnym obecnie opowieściom o wampiryzmie energetycznym. Szczególną odmianę tych opowieści stanowią publikowane głównie w serwisie YouTube tutoriale, zawierające rożnego rodzaju omówienia i wyjaśnienia koncepcji wampiryzmu energetycznego oraz zestawy wskazówek mających umożliwić odbiorcom zidentyfikowanie złodziei energii oraz neutralizację ich negatywnego oddziaływania (Grochowski 2017).

Celem niniejszego artykułu jest zaprezentowanie wyników szczegółowej analizy tutoriali antywampirycznych i próba odpowiedzi na pytanie o status tych materiałów, a zwłaszcza status prezentowanej w nich wiedzy. Chodzi mi przede wszystkim o to, aby ustalić, na ile uprawnione jest traktowanie tego typu przekazów jako przykładów współczesnego cyberfolkloru ${ }^{1}$. Pojawiające się tu wạtpliwości wynikają z tego, że sposób prezentowania internetowych opowieści o wampiryzmie energetycznym odbiega od typowych narracji folklorystycznych w co najmniej w dwóch zasadniczych aspektach. Po pierwsze, autorzy filmów prezentują się często jako profesjonaliści, którzy dysponują wiedzą o charakterze eksperckim lub ezoterycznym - byłaby to więc wiedza sytuująca się w opozycji do folkloru rozumianego źródłowo jako „wiedza ludu”, czyli wiedza powszechna (ogólnodostępna w obrębie określonej społeczności), a zarazem potoczna i na swój sposób amatorska (wernakularna), czyli alternatywna w stosunku do form oficjalnych czy profesjonalnych (Kowalski 1990: 111-116). Po drugie, w swoich wystąpieniach youtuberzy odwołują się często do indywidualnych doświadczeń i samodzielnych poszukiwań lub studiów, co również w pewnym zakresie kontrastuje z folklorem rozumianym jako wiedza wytwarzana i transmitowana kolektywnie (Bartmiński 1990: 8-9).

1 Omawiane tutoriale stanowią formę wypowiedzi charakterystyczną dla zapośredniczonej komputerowo komunikacji elektronicznej, dlatego zaliczam je do zjawiska określanego w polskiej literaturze przedmiotu przy pomocy takich terminów jak cyberfolklor, e-folklor, folklor elektroniczny/internetowy czy netlor. Określenia te mają w moim przekonaniu charakter synonimiczny i odnoszą się do wszystkich form folkloru funkcjonujących w cyfrowych kanałach komunikacji (por. Grochowski 2013). 
W swoich badaniach posłużyłem się analizą materiałów zastanych, które stanowiła próba 60 filmów opublikowanych w serwisie YouTube (30 polskojęzycznych i 30 angielskojęzycznych) wraz z towarzyszącymi im opisami, danymi statystycznymi (liczba odsłon i komentarzy oraz oceny) oraz komentarzami widzów. Ze względu na rozmiary serwisu YouTube (olbrzymia ilość filmów niemożliwa do systematycznego przejrzenia) oraz specyfikę źródeł (pliki wideo uniemożliwiające zastosowanie wyszukiwania pełnotekstowego) podstawowym kryterium zastosowanym $\mathrm{w}$ doborze próby badawczej był tytuł filmu, w którym musiała pojawić się fraza wampir energetyczny/wampiryzm energetyczny lub energy vampire/psychic vampire. Dokonałem również ogólnej analizy kanałów, na których opublikowano interesujące mnie filmy, zwracając uwagę na typ oferowanych przez nie treści oraz wszelkie informacje o autorach, linki do źródeł zewnętrznych, reklamy produktów, oferty usług itp.

Analizowane filmy mają zróżnicowaną długość (od ok. trzech minut do około godziny) i są bardzo różnorodne pod względem technicznym (jakość nagrania, montaż). Część z nich ma charakter profesjonalny, część zaś to nagrania typowo amatorskie, dokonywane za pomocą kamery internetowej w domowej scenerii. Stosowane w nich formy wypowiedzi to najczęściej swobodna pogawędka, rodzaj nieformalnego, popularnego wykładu, paradziennikarska narracja informacyjna lub internetowy tutorial. We wszystkich tych formach obecna jest jednak konwencja poradnika, pojawiają się w nich bowiem różne rady na temat tego, jak rozpoznać wampiryzm energetyczny i jak sobie z nim radzić. Materiały te publikowane są najczęściej - choć nie zawsze - w obrębie wideoblogów na kanałach poświęconych coachingowi i rozwojowi osobistemu albo wiedzy ezoterycznej i duchowości. Okazjonalnie można je także spotkać na kanałach dotyczących zdrowia i medycyny holistycznej albo różnego rodzaju zjawisk paranormalny i niewyjaśnionych.

$\mathrm{Na}$ uwagę zasługuje fakt, że tutoriale antywampiryczne cieszą się sporą popularnością zarówno wśród youtuberów, jak i wśród widzów. Oglądalność materiałów w języku polskim waha się w granicach 2-50 tysięcy odsłon, natomiast najpopularniejsze filmy w języku angielskim mają ponad 500 tysięcy odsłon. Większość z nich wywołuje też liczne reakcje odbiorców przybierające formę ocen oraz komentarzy. Najpopularniejsze materiały w języku polskim mają kilkaset ocen pozytywnych oraz 2060 komentarzy, natomiast najpopularniejszy z badanych filmów w języku angielskim zgromadził aż 9 tysięcy ocen pozytywnych i ponad 2 tysiące komentarzy. Analiza danych statystycznych oraz działań youtuberów i reakcji widzów prowadzi do wniosku, że omawiane narracje mają stosunkowo duży zasięg i podlegają nieustannej retransmisji w obrębie względnie ustabilizowanych grup nadawców i odbiorców, którzy wykazują nie tylko zainteresowanie tematem wampiryzmu, ale też stwarzają wyraźne zapotrzebowanie na współczesne opowieści o wampirach. Tym samym można powiedzieć, że mamy tu do czynienia z podstawowym warunkiem zaistnienia sytuacji folklorotwórczej, jakim jest „oddolna” społeczna potrzeba podjęcia twórczej aktywności. Jednak sposób zaspokajania tej potrzeby oraz formy narracyjne, jakie zostają w tym przypadku wytworzone, znacznie odbiegają od tych, z którymi spotykaliśmy się w tradycji ustnej i ludowych podaniach o tematyce demonicznej.

\section{W stronę narracji eksperckich i indywidualizmu}

Można wskazać co najmniej kilka charakterystycznych cech, które sprawiają, że tutoriale antywapiryczne zbliżają się pod pewnymi względami do narracji eksperckich. Przede wszystkim - jak sygnalizowałem - są one najczęściej publikowane na kanałach, 
których ogólna specyfika wskazuje na to, że ich autorzy podejmują wiele celowych i przemyślanych działań zmierzających do tego, by uzyskać status eksperta $\mathrm{w}$ zakresie podejmowanej tematyki. Chodzi tu $\mathrm{z}$ jednej strony o względne ograniczenie zakresu poruszanych zagadnień do określonego, choć zarazem dość swobodnie interpretowanego obszaru wiedzy (np. ezoteryka, coaching, medycyna holistyczna), z drugiej strony o regularne publikowanie materiałów filmowych, mające na celu nie tylko przyciąganie i utrzymywanie uwagi widzów, ale także przekonanie ich, że autor jest dobrze obeznany $\mathrm{z}$ daną problematyką oraz zajmuje się nią w sposób systematyczny i pogłębiony. Poetyka filmów (np. liczne zwroty do słuchaczy z prośbami o oceny, komentarze, subskrybowanie kanału), a także pewne elementy zamieszczane w obrębie kanałów (np. logo kanału, tzw. intro, czyli prezentację kanału i autora, linki do prowadzonych przez autora stron internetowych, blogów czy profili w mediach społecznościowych) wskazują na to, że mamy tu do czynienia ze świadomymi zabiegami służącymi tworzeniu marki i budowaniu wokół niej społeczności widzów. Często uwidaczniają się tu również wyraźne aspekty komercyjne działalności poszczególnych youtuberów. W trakcie odtwarzania filmów wyświetlane są reklamy, pod materiałami pojawiają się linki do stron, gdzie oferowana jest sprzedaż produktów oraz różnego rodzaju płatne usługi i konsultacje świadczone przez autorów. W ten sposób próbują oni wykorzystać rynkowy potencjał tworzonej przez siebie marki, czerpiąc z niej korzyści finansowe, a zarazem po części przekształcając tworzącą się wokół kanału wspólnotę komunikacyjną w grupę konsumentów.

W narracjach dotyczących wampiryzmu energetycznego autorzy często podkreślają, że podejmują tę tematykę na wyraźną prośbę widzów, którzy zwracają się do nich z licznymi pytaniami dotyczącymi tego zagadnienia. W ten sposób youtuberzy kreują swój wizerunek jako osób, które już są rozpoznawane i identyfikowane przez odbiorców jako profesjonaliści w danej dziedzinie. Dodatkowo w swoich wystąpieniach nierzadko odwołują się oni do innych aspektów własnych działań zawodowych, wspominając o napisanych artykułach, opublikowanych książkach, udzielanych konsultacjach, przeprowadzonych zabiegach, a nawet założonych „klinikach”. Jako element dyskursu eksperckiego można też uznać fakt, iż niektórzy autorzy w trakcie swych prezentacji korzystają z profesjonalnych pomocy dydaktycznych, posługując się tablicami, rysunkami, wykresami czy pokazami slajdów; część materiałów przypomina nawet krótkie filmy popularnonaukowe.

Jak wspomniałem na wstępie, prócz aspektu eksperckiego specyficzną cechą tutoriali antywampirycznych jest również to, iż w wielu miejscach uwidacznia się w nich dość wyraźna perspektywa indywidualistyczna. Chodzi tu przede wszystkim o trzy kwestie. Po pierwsze, autorzy często opowiadają o wydarzeniach i sytuacjach z własnego życia, które wydają się mieć charakter jednostkowy i w związku z tym - przynajmniej na pierwszy rzut oka - trudno uznać je za przykłady narracji folklorystycznych, stanowiących uaktualnienie obiegowych wątków i motywów. Przykładem takiej opowieści może być relacja Evana Branda na temat tego, jak jego bliscy reagowali na podejmowane przez niego wysiłki:

I can't tell you how much scepticism about me becoming an entrepreneur and starting my own wellness clinic and starting my own supplement company and becoming a published author things like that, how much backlash I've had like - you know: "you should just get a nine-to-fife" or "are you sure, you don't want to go back to school", things like that. And now that I do have my book in bookstores my family's like: "O! congratulations", and they're so excited for me, but back when I was telling people about my goals they were all like: "there's no way you're going to be able to do this thing". So that's my personal experience (Evan Brand). 
Po drugie, wielu autorów sygnalizuje, czy też w różny sposób sugeruje, że jest osobami wyjątkowymi. Może tu chodzić o wspomniane wcześniej podkreślanie szczególnego statusu youtubera jako eksperta czy nauczyciela albo człowieka sukcesu czy osoby publicznej. Na ten aspekt kładzie nacisk Czarownica Joanna Wiśniewska:

Jeżeli chodzi o wampiry świadome, to znalazłam na nie bardzo dobry sposób [...], moje filmy, nazwisko, adres, to co robię, świadomie wpuszczam w internet [...]. Wiem, że żeby pracować w tej formie, w jakiej ja pracuję, trzeba mieć twardy tyłek, dlatego, że się zdarza hejt, katolicynawracacze, różne gatunki i podgatunki ludzi - na to jestem uodporniona [...]. Skoro mój wizerunek i po części moja energia jest na kanale, na mediach, jest bardzo łatwy dostęp tych wampirów energetycznych, które są świadomymi wampirami energetycznymi [...]. Jest bardzo dobra obrona przed takimi wampirami. Ja kierunkuję całą swoją negatywną energię na to, że jeżeli ktoś będzie chciał się pode mnie podczepić, to to dostanie. Jesteś wampirem, zrobiłeś to świadomie [...], dostajesz ruzdeczką, bo ja tu jestem na tym kanale $\mathrm{z}$ moim wizerunkiem nauczycielem (Czarownica Joanna Wiśniewska 1).

Często jednak autorzy tutoriali dają też do zrozumienia, że posiadają wyjątkowe właściwości duchowe i umiejętności (np. mają szczególnie silną aurę lub widzą ją u innych osób) albo też prezentowana przez nich wiedza jest wynikiem osobistych doświadczeń, studiów czy oryginalnych przemyśleń. W tym zakresie pojawiają się też niekiedy wzmianki o konieczności indywidualnego podejścia do problemów związanych $\mathrm{z}$ wampiryzmem oraz dostosowania pewnych działań do konkretnych sytuacji życiowych poszczególnych osób. Przykładowo, Grace Carter, opowiadając o spotkaniu z umierajaca koleżanką, wyraźnie sugeruje, że jej poziom „uduchowienia” jest zdecydowanie wyższy niż większości zwykłych ludzi: „Ja przez koleżankę na łożu śmierci miałam powiedziane, że ja mam aureolę nad głową [...]. Ja się nawet jej pytam: »Co ty masz na myśli?« A ona mówi: »Wyglądasz jak święta«. To jest troszeczkę wyższa szkoła jazdy” (Grace Carter). Z kolei Jasnowidz Vanessa w jednym ze swych filmów stwierdza: „Wielokrotnie miałam do czynienia $\mathrm{Z}$ wampirem energetycznym. $\mathrm{Z}$ racji moich przemyśleń $\mathrm{w}$ tej kwestii i doświadczeń, postanowiłam opowiedzieć wam o tym właśnie w tym filmie" (Jasnowidz Vanessa 1).

Swoisty indywidualizm tutoriali antywampirycznych zaznacza się jednak najwyraźniej w zakresie ogólnych założeń ideologicznych i koncepcyjnych, jakie leżą u podłoża prezentowanych $\mathrm{w}$ nich wyjaśnień i rad. Podstawowym zespołem idei jest tu bowiem indywidualny rozwój człowieka, świadomy i przemyślany wybór drogi życiowej oraz wykorzystanie i rozwijanie własnego potencjału. W tej perspektywie wszelkie relacje, działania i zobowiązania wspólnotowe (np. rodzinne, zawodowe, sąsiedzkie) schodzą na dalszy plan i są wyraźnie marginalizowane; często wręcz zaleca się zerwanie tych relacji, jeśli stanowią one przeszkodę na drodze rozwoju osobistego czy utrudniają realizację indywidualnych celów.

Jeżeli gdzieś w jakimś momencie coś ci nie służy, od czegoś robisz się chora, odsuń się od tego. Zastanów się, co tak naprawdę ci dokucza [...] przeprowadź medytację. To warto zrobić [...] odsunąc się od tego, co jest dla ciebie niedobre i naprawdę zająć się sobą [...], robić to, co sprawi ci przyjemność, cieszyć się życiem, bo po to tutaj jesteśmy. Nikt się tobą nie zajmie tak, jak ty sama (Grace Carter).

Staramy się żyć świadomie, świadomie kontrolować nasze myśli, działania i także decydujemy się na wybór własnej drogi [...]. Ofiarami wampirów są najczęściej osoby [...], które idą drogą, która jest niezgodna $\mathrm{z}$ ich własnym życzeniem. Np. lubią malować, ale nigdy nie malują i thumaczą to sobie tym, że nie maja czasu, albo ich wymarzonym zawodem jest np. tworzenie bukietów, a pracują w księgowości, gdyż boją się, że poprzez tworzenie bukietów nie będą się w stanie 
utrzymać i przez to rezygnują [...] ze swojej pozytywnej drogi, drogi zgodnej z ich powołaniem i przez to są osłabione, gdyż robią coś przeciwko sobie, przeciwko swojej duszy (Maria Bucardi 1).

If everything else fails it gets out of hand, remember you are number one in your book, so distance yourself from them as much as you can [...]. Keep in mind that you're the most important resource in your life and if you're being affected by energy vampires you may need to take drastic measures to eliminate them (Rene Bastarache).

Prezentowane w powyższych i wielu innych wypowiedziach koncepcje i praktyczne wskazówki można postrzegać jako elementy charakterystyczne dla kultury późnej nowoczesności, w której kluczowymi kwestiami stają się indywidualne projekty tożsamości (Giddens 2010: 106-114) oraz możliwość dokonywania wyborów (Mathews 2005: 34-35). Doświadczenie jednostki, jej autonomia, samowystarczalność i potencjał stają się w tym ujęciu dominującymi wartościami, wobec czego - inaczej niż w kulturach typu tradycyjnego - wszelkie praktyki wspólnotowe, w tym również praktyki narracyjne, nie sa tu traktowane jako aktualizacje zastanych, „naturalnych” i gotowych do wykorzystania wzorców. Przeciwnie, często podkreśla się konieczność modyfikowania owych wzorców i dostosowywania ich do życiowej sytuacji każdego człowieka, która ujmowana i wyjaśniana jest nierzadko za pomocą narracji uznawanych również za jednostkowe i niepowtarzalne.

\section{Netlor i opowieści przy cyfrowym ognisku}

Szczegółowa analiza treści i formy tutoriali antywampirycznych oraz sposobu ich odbioru prowadzi jednak do wniosków zgoła odmiennych. Okazuje się bowiem, że w kilku różnych aspektach zbliżają się one do modelu komunikacyjnego charakterystycznego dla tekstów folkloru. Przede wszystkim, w szerszej perspektywie wystąpienia youtuberów - mimo opisanych powyżej cech oraz praktyk i deklaracji autorów - trudno uznać za oryginalne. Stanowią one raczej warianty pewnego wspólnego, ogólnego modelu opowiadania o wampiryzmie energetycznym i cechuje je znaczny stopień powtarzalności i typowości, przy czym powtarzalność ta jest widoczna na kilku poziomach.

Po pierwsze, jest ona bardzo wyraźna, jeśli chodzi o ogólny model interpretowania rzeczywistości i tłumaczenia istoty wampiryzmu energetycznego. Zasadniczo mamy tu do czynienia z dwoma, częściowo alternatywnymi, częściowo uzupełniającymi się modelami, które są $\mathrm{w}$ różny sposób kombinowane, przetwarzane i rozwijane przez poszczególnych youtuberów. Pierwszy $\mathrm{z}$ nich ujmuje zagadnienie w kategoriach psychologicznych jako swego rodzaju zespół zaburzeń emocjonalnych, drugi odwołuje się do ezoterycznych koncepcji zaczerpniętych z różnych religii Dalekiego Wschodu i mówi o zakłóceniach w zakresie gospodarowania energią życiową człowieka (zob. Grochowski 2017).

Po drugie, autorzy tutoriali zakładają - i często werbalizują to założenie w swoich wystąpieniach - że temat wampiryzmu energetycznego jest znany, a widzowie posiadają w tym zakresie pewien zasób wiedzy i doświadczeń, który można uznać za powszechny. Przykładowo, Maria Bucardi rozpoczyna jeden ze swoich filmów słowami: „Moi kochani, myślę, że każdy z nas miał w swoim życiu już taki moment, w którym spotkał się z wampiryzmem energetycznym" (Maria Bucardi 1). Treści prezentowane przez youtuberów są więc przez nich traktowane nie jako nowe odkrycia, ale jako pewne uzupełnienie albo uporządkowanie wiedzy już istniejącej. Jak zauważa jeden z nich: „I felt as it was important for me to make this video to make other people aware to add my voice to the group of voices already in existence talking about this energy vampires" 
(NinjightNationCorp). Co więcej, podkreśla się tu niekiedy, że wiedza ta, jest bądź powinna być wiedzą wspólną, to znaczy przekazywaną swobodnie i dostępną wszystkim członkom danej społeczności. Wskazuje na to wyraźnie np. Czarownica Joanna Wiśniewska, stwierdzając: „myślę, że dużo wiadomości macie już zebrane, ale liczę na was, że również te wiadomości będziecie przekazywać. [...] Mam nadzieję, że będziecie mówić o swoich doświadczeniach z wampirami energetycznymi”" (Czarownica Joanna Wiśniewska 1).

Po trzecie, powtarzalność bardzo wyraźnie zaznacza się w obrębie formułowania szczegółowych wskazówek i rad dotyczących identyfikacji wampirów energetycznych oraz sposobów radzenia sobie z nim (zob. Grochowski 2017: 235-236). Po czwarte wreszcie, również wspomniane wcześniej opowieści o indywidualnych doświadczeniach życiowych w szerszej perspektywie okazują się typowe i powtarzalne, wpisując się w kilka stałych schematów narracyjnych służących do relacjonowania spotkań z wampirami energetycznymi. Ta ostatnia kwestia wydaje się szczególnie istotna. W perspektywie nadawczo-odbiorczej tutoriale antywampiryczne konstytuują bowiem charakterystyczną dla wielu platform i kanałów komunikacji elektronicznej sytuację folklorotwórczą nazywaną niekiedy przez badaczy nowych mediów cyfrowym ogniskiem (digital campfire; Chess, Newsom 2015: 78-80). Chodzi mianowicie o to, że opublikowany materiał stwarza swego rodzaju okazję do asynchronicznego spotkania jego odbiorców, a udostępniana infrastruktura techniczna umożliwia każdemu zabranie głosu i zachęca do zaprezentowania własnych opowieści. W komentarzach pod filmami wiele osób przedstawia więc swoje doświadczenia $\mathrm{z}$ wampiryzmem energetycznym w formie bardziej lub mniej rozbudowanych narracji. Są to $\mathrm{z}$ reguły opowieści o doświadczeniach własnych lub członków rodziny, przyjaciół czy znajomych (co istotne, często także „znajomych znajomych”), relacjonowane za pomocą wspomnianych wyżej utrwalonych struktur konceptualno-narracyjnych. Mamy tu więc do czynienia $\mathrm{z}$ typowym procesem folkloryzacji. Indywidualne i niepowtarzalne sytuacje życiowe podlegają specyficznej obróbce, są dostosowywane do istniejących konwencji oraz schematów wyobrażeniowych i narracyjnych (Kadłubiec 1999: 68-69). Osoby opowiadające korzystają z określonej tradycji narratorskiej, a tym samym - jak zauważa Janina Hajduk-Nijakowska: „ekspresja emocjonalna i poznawcza jednostki znajduje w [tej tradycji] formuły słowne i obrazowe, stereotypy, wierzenia, sposoby rozumienia i interpretacji świata pomagajace jej werbalizować przeżycia, konstruować wypowiedź i zrealizować potrzebę mówienia" (Hajduk-Nijakowska 2016: 76). Jednocześnie możemy tu zaobserwować charakterystyczną dla współczesnych przekazów folklorystycznych ekspansję konwencji memoratowej, która polega na prezentowaniu różnego rodzaju zdarzeń jako znanych $\mathrm{z}$ autopsji, co sprzyja uwiarygodnieniu ich prawdziwości. (Simonides 1981: 34-35). Przykładowo, jednym z częściej powracających typów narracji są opowieści o przyjacielu, którego wampiryczna aktywność ujawnia się lub potęguje i zostaje odkryta w pewnych szczególnych okolicznościach:

Wydawało mi się, że mam ochronę przed wampirami, ale ostatnio okazało się, że moja przyjaciółka po chorobie (miała wylew), nagle stała się wampirem energetycznym... dwa razy byłam u niej i dwa razy miałam potem problem na ulicy, szłam jak pijana, nie mogąc nawet oddychać, bo mnie coś dławiło... musiałam stanąć i pomagać sobie dojść do jakiej-takiej normalności, bo bym do domu nie dojechała... jestem zaskoczona, bo przedtem nic takiego nie było... szok totalny... (Czarownica Joanna Wiśniewska 1$)^{2}$.

2 W cytatach z komentarzy umieszczanych pod filmami zestandaryzowano pisownię zgodnie $\mathrm{z}$ aktualnymi zasadami polskiej ortografii i interpunkcji. 
Innym przykładem mogą być liczne opowieści o „wampirycznych matkach”. Struktura fabularna sprowadza się tu do aktualizacji dwóch zasadniczych elementów: nieustanne narzekanie i krytykanctwo (ilustrowane często rozmaitymi przykładami) oraz wyprowadzka z domu (planowana bądź zrealizowana):

Moja mama jest wampirem energetycznym. Wiecznie narzeka i obwinia wszystkich o wszystko, ale sama nigdy nie widzi w sobie problemu, nawet jeśli jej wina jest czasem oczywista. Skłócona z połową rodziny, uparcie twierdzi, że to wszyscy całe życie jej robią na złość i są przeciwko niej, i już nawet nie widzi, jak nie raz ktoś wyciąga do niej rękę. Kiedyś widziała mnie, jak robiłem pompki w pokoju i popatrzyła się na mnie jak na idiotę i stwierdziła, że mam coś z głową... co bym w życiu nie starał się robić dobrego dla siebie, to ona wiecznie dopatruje się negatywów. Jeżdżę motorem - zabiję się, chodzę na siłownię - żrę te świństwa (chodzi o białko) i wziąłbym się lepiej za jaką robotę, wracam z treningu wieczorem - gdzieś się włóczę. Mam jej dość i w tym roku chcę się wyprowadzić $\mathrm{z}$ domu, a ona niech się użera $\mathrm{z}$ drugim synem, tym razem alkoholikiem (Robert Marchel).

W komentarzach zamieszczanych pod tutorialami dominującym elementem są jednak nie narracje, lecz dyskusje. $Z$ jednej strony widzowie prezentują w nich zróżnicowane poglądy, dość często nie zgadzają się także ze stanowiskiem i wyjaśnieniami przedstawionymi w filmie lub z poglądami innych odbiorców. $Z$ drugiej strony, w szerszej perspektywie, można tu jednak dostrzec wyraźne ustabilizowanie i „uwspólnienie” poglądów i ocen. Charakterystyczne jest chociażby to, że zdecydowana większość widzów pozytywnie ocenia wystąpienia youtuberów, co znajduje odbicie zarówno w statystykach, jak i w komentarzach. W okresie prowadzenia badań najpopularniejszy z materiałów polskojęzycznych miał 443 oceny pozytywne i tylko 29 negatywnych; najpopularniejszy materiał angielskojęzyczny odpowiednio 9000 i 774 ocen. Wiele osób dziękuje autorom tutoriali za udzielone wyjaśnienia i wskazówki, podaje przykłady świadczące o ich słuszności i skuteczności, opowiada historie potwierdzające i/lub uzupełniające zaprezentowane koncepcje. Tworzy się tu więc swego rodzaju wspólnota, która posiada wiele cech typowych dla nieformalnych grup o charakterze folklorystycznym, przede wszystkim zaś pełni trzy zasadnicze funkcje.

Po pierwsze, jest typem wspólnoty interpretacyjnej. Przynależność do niej wiąże się z podzielaniem określonych sposobów postrzegania i rozumienia rzeczywistości, sposoby te są zaś rozpowszechniane i utrwalane w procesie spontanicznej wymiany informacji w obrębie grupy. Po drugie, uczestnictwo w niej ma wymiar tożsamościowy. Mamy tu do czynienia ze społecznością ludzi o podobnych doświadczeniach życiowych - niekiedy przybierającą wręcz postać wspólnoty ofiar - którzy uznają owe doświadczenia za ważny element swojej biografii, a także rozpoznają u siebie zbieżne cechy traktowane jako elementy konstrukcji tożsamościowych. Oglądanie tutoriali antywampirycznych i czytanie dyskusji w komentarzach pod nimi, a także zabieranie głosu i przedstawianie własnych historii staje się dla nich elementem poszukiwań związanych $\mathrm{z}$ próbą zrekonstuowania swej tożsamości indywidualnej poprzez umieszczenie jej w szerszym kontekście tożsamości zbiorowej i odnalezienie ludzi podobnych do siebie. Szczególnie wyraźnie uwidacznia się to $\mathrm{w}$ materiałach angielskojęzycznych, gdzie konstrukcje te zyskały nawet leksykalny wyraz w postaci etykiet empath lub sensitive:

Thank you for making this video and sharing your insight and wisdom. I am an empath and I am currently going through a time of self discovery through this gift. Being an empath started to get out of control, I began questioning my sanity and grew increasingly anxious with existing in the world. So I started my search for answers and guidance and came across your video and it has truly 
helped me greatly. I am now more aware of this power I possess, and how I can keep the essence of me and maintain my energy. Thank you so much! (Matthew Rosenberg).

Autorzy i odbiorcy tutoriali antywampirycznych tworzą środowisko, w obrębie którego jest rozpowszechniana i - co ważniejsze - stosowana również wiedza o charakterze praktycznym. Można więc powiedzieć, że są to grupy, których członkowie podejmują działania jakimś zakresie podobne i w pewnym sensie wspólne, choć oczywiście pozostają w przestrzennym oddaleniu. Inaczej rzecz ujmując, mamy tu do czynienia ze mikrospołecznościami, które oczekują od swoich członków pewnego typu zachowań, a w każdym razie sugerują im podejmowanie (bądź unikanie) określonych działań. Youtuberzy oraz ich widzowie nie tylko przekazują sobie wzajemnie różne rady i wskazówki, ale także zdają relacje $\mathrm{z}$ ich zastosowania, mówią o efektach, jakie przyniosły i zmianach, jakie wywołały w ich życiu. Jedna z osób oglądających program Czarownicy Joanny Wiśniewskiej pisze: „Wczoraj zrobiłam ten rytuał. Odcięłam wampira i jednocześnie skończyłam znajomość. Niestety to nie koniec. Ta osoba atakuje mnie w pracy słownie, bredzi i krzyczy. I co teraz?????” (Czarownica Joanna Wiśniewska 2). Innym przykładem takiego kolektywnego działania, zmierzającego do rozwiązania konkretnego problemu może być sytuacja, jaką obserwujemy w następującej wymianie komentarzy:

Clare

I'm stuck with an energy vampire for the next couple of months or so... or until I find a proper job. I'm in a "survival job" at the moment while I search for a proper job and it's in a call center... anyway, one of the people in the call center is constantly talking very loudly... it's like a fork scraping against a plate for me and I don't know how to block it out because I have to wear earphones for the job, so it's not like I can listen to music while I work. Other people working with me are also finding it frustrating, but as an empath, I'm particularly sensitive to this man's oppressive voice. Because I've complained once (the management let me move further away from him) I don't like to complain again... he seems to have gotten louder now.

Evan Brand

Don't give up, keep pressing the issue until you reach a resolution. Not worth living in misery. Best of luck.

Clare

+Evan Brand Thanks. I'm working on it.

Green Onions

Maybe you can keep flowers on your desk, pretty postcards, crystals, a small pitcher of ice water with lemons to drink, a little bit of something invigorating like peppermint oil to smell, etc.

Evan Brand

+Orange Popcicles \& Lemonade Those are great ideas! This is what community is about. Thank you.

Don X

I've worked in a couple of call centers before. It's a VERY challenging job. I was lucky in those scenarios as far as co-workers go. I was reading a book on HSP, speaking of empaths, and the author suggested essences. She steered me to featherhawk. The lady who makes the essences, Nanci, is great. And her essences for HSPs saved my sanity. The yarrow blend works very well. She has a great online catalog with helpful descriptions. I don't know if it'll drown out big mouth, but it can only help. 
Clare

+Don X Thanks for the suggestion - appreciate it. :)

Clare

+Evan Brand I did follow up with an email to the head of the organization. They took it seriously and HR spoke to the man and moved him further away from our team... so far, things have been much better. Thanks again for your input :) (Evan Brand).

Tworzenie się mikrospołeczności wokół tutoriali antywampirycznych oraz właściwy im kolektywny sposób myślenia i działania znajdują wsparcie w zmianach technologicznych zachodzących w ostatnich latach w obrębie serwisu YouTube. Szczególne znaczenie i potencjał ma zwłaszcza wprowadzenie możliwości organizowania transmisji online, które pozwalają w znacznym stopniu przezwyciężyć ograniczenia modelu komunikacji asynchronicznej i zbliżyć się do charakterystycznego dla „klasycznych” sytuacji folklorystycznych modelu komunikacji synchronicznej. Program nadawany na żywo jest pozbawiony montażu oraz innych zabiegów stosowanych w audycjach nagrywanych wcześniej (np. precyzyjnego scenariusza, możliwości nagrywania powtórek), a tym samym nadawca może tu wykorzystywać ograniczony zestaw środków wyrazu, niewiele wykraczający poza to, z czym mamy do czynienia w oralnej komunikacji typu face to face. Jeszcze ważniejsze jest jednak to, że formuła ta gromadzi grupę widzów oglądających przekaz w tym samym czasie i komunikujących się ze sobą oraz $\mathrm{z}$ nadawca za pomocą chatu umieszczonego tuż obok okna, w którym wyświetlany jest program. Taka technologia umożliwia wielostronną wymianę informacji pomiędzy wszystkimi uczestnikami sytuacji komunikacyjnej. I choć widzowie są zasadniczo pozbawieni możliwości używania wizualnych i akustycznych środków wyrazu, to jednak ich głos jest „słyszalny”, mogą wiec również bezpośrednio wpływać na przebieg transmisji, np. wyrażając opinie na jej temat czy mówiąc o swoich wrażeniach. Mamy tu więc do czynienia $\mathrm{z}$ typowym przykładem sprzężenia zwrotnego, które w sytuacji wykonawczej tekstów folkloru sprawia, że ich kształt jest na bieżąco modyfikowany przez nadawcę pod wpływem różnego rodzaju sygnałów, jakie kierują do niego odbiorcy (Dundes 1977: 96-97). Podobnie w organizowanych w serwisie TouTube transmisjach online ich autorzy zwracaja uwage i reaguja na zachowania swoich widzów, na bieżąco sprawdzając, ile osób dołącza do transmisji, komentując ich wypowiedzi, odpowiadajac na pytania, czy witając i pozdrawiając „stałych bywalców”. Przykładowo, Czarownica Joanna Wiśniewska rozpoczyna jedno $\mathrm{z}$ takich spotkań w następujący sposób:

Witam was wszystkich bardzo serdecznie. Jeszcze tych wszystkich dużo nie jest, tak że poczekamy, bo myślę, że o 22 wiele osób do nas dotrze, żeby przyłączyć się do naszego rytuału. Mam nadzieję, że wasze świece sa przygotowane. Dzisiaj rytuał ogólny, jak to w środy w zwyczaju mamy, czyli robimy sobie wspólne działania, co tam sobie umyślimy, to sobie i działamy" (Czarownica Joanna Wiśniewska 2).

Watro podkreślić, że w takiej sytuacji możliwe jest nie tylko wielokierunkowe i synchroniczne przekazywanie informacji, ale także wspólne podejmowane pewnych działań. Uczestnicy transmisji online mogą na przykład pod kierunkiem prowadzącego tutorial wykonywać czynności o charakterze rytualnym, w tym również rytuały odcięcia od wampirów energetycznych. Taka praktyka synchronicznych działań wspólnotowych - które zresztą często podejmowane są cyklicznie, np. w określony dzień tygodnia - ma w ocenie uczestników tego typu transmisji większą wartość niż wykonywanie rytuałów 
samodzielnie i asynchronicznie na podstawie wskazówek dostępnych w tutorialu, choć ta ostatnia forma jest też dostępna dla tych, którzy $\mathrm{z}$ różnych powodów nie mogli w danym czasie zrealizować proponowanych form aktywności. Taka opinia zaznacza się wyraźnie na przykład w wypowiedzi wspomnianej wcześniej Czarownicy Joanny, podsumowującej jeden z prowadzonych na żywo cotygodniowych rytuałów: „[...] nie wiem, jak wasze odczucia, ale ja naprawdę lubię z wami robić te środowe rytuały [...]. Pokrzywka, jak nie zdążyłaś, to sobie zrób w innym czasie, spokojnie, dlatego, że to ty pracujesz nad swoją energią. To, że my to robimy w kupie, to wiadomo, że to jest fajnie, ale tak, można to robić samemu" (Czarownica Joanna Wiśniewska 2).

\section{Podsumowanie}

Przeprowadzone przeze mnie badania i przedstawione w niniejszym artykule analizy prowadzą do wniosku, że status publikowanych w serwisie YouTube materiałów dotyczących wampiryzmu energetycznego cechuje niejednorodność i pewna paradoksalność.

Zarówno intencje autorów, jak i związane $\mathrm{z}$ tymi intencjami pewne zabiegi formalne, a także zasadnicze idee leżące u podstaw samej koncepcji kradzieży ludzkiej energii wskazują na to, że mamy tu do czynienia $\mathrm{z}$ przekazami prezentującymi profesjonalną wiedzę ekspercką - niekiedy sprawiającą zarazem wrażenie wiedzy ezoterycznej - która ma zastosowanie w działaniach związanych $\mathrm{z}$ rozwojem osobistym i realizacją indywidualnych projektów tożsamościowych, czyli w praktykach uznawanych zwykle za charakterystyczne dla warunków późnej nowoczesności. Pod tym względem współczesne internetowe narracje o wampirach energetycznych wydają się dalekie od tradycyjnych wierzeń demonicznych, a sposób działania i intencje narratorów znacznie odbiegają od tego, $\mathrm{z}$ czym mieliśmy do czynienia $\mathrm{w}$ przypadku folkloru i obecnych w nim podań rozwijających motyw ,żywego trupa”.

$Z$ drugiej strony treści przekazywane przez autorów tutoriali cechuje duży stopień powtarzalności i typowości, a zarazem są one bardzo często traktowane jako elementy wiedzy wspólnej i powszechnej, pozbawionej konkretnego autorstwa, która jest jedynie zbierana, przypominana, porządkowana, ewentualnie uzupełniana i rozwijana przez poszczególnych youtuberów. Pod tym względem analizowane materiały wyraźnie zbliżają się do modelu wiedzy kolektywnej, której wytwarzaniu i transmitowaniu służą teksty folkloru. Jeszcze ważniejsze i ciekawsze wydaje się jednak to, że filmy podejmujące problematykę wampiryzmu energetycznego często odgrywają rolę „cyfrowych ognisk”, gromadzących liczną publiczność i dających pretekst do tworzenia i przedstawiania innym widzom własnych opowieści. Część autorów świadomie zmierza przy tym do wykreowania wokół swego kanału bardziej stabilnych mikrospołeczności, które będą nie tylko podzielały wspólne zainteresowania, wartości czy sposoby postrzegania i interpretowania rzeczywistości, ale będą także podejmowały wspólne działania. W tym zakresie szczególnie interesujący i wart dalszych obserwacji jest rozwój technologii streamingowych, umożliwiających komunikację synchroniczną i podejmowanie praktyk o wyraźnym charakterze wspólnotowym. Uczestnicy takich sesji, mimo fizycznego oddalenia, działaja w sposób bardzo zbliżony do tego, jaki cechował praktyki narracyjne i obrzędowe właściwe dla folkloru. Oczywiście trzeba podkreślić, że omawiane narracje antywampiryczne funkcjonują w ramach komunikacji zapośredniczonej komputerowo, a pod względem treści i formy mają niewiele wspólnego z ludowymi opowieściami o wampirach (por. Grochowski 2017: 237-238). Kiedy jednak wielu widzów w tym samym momencie włącza się aktywnie i twórczo w transmisję online dostępną poprzez serwis YouTube, a w dodatku wszyscy zapalają przed swoimi 
komputerami świece, metafora „cyfrowego ogniska” staje się już mniej metaforyczna. W tym kontekście można postawić tezę, że tutoriale antywampiryczne oraz związane $\mathrm{z}$ nimi zachowania nadawców i odbiorców stanowią bez wątpienia współczesną formę cyberfolkloru. Formę tę należałoby jednak postrzegać nie jako kontynuację tradycyjnych wierzeń demonicznych, lecz jako nowy fenomen funkcjonujący zgodnie z ogólnymi mechanizmami folkloru.

\section{Bibliografia}

Źródla

Agnieszka Tarocistka

[ATAKI ENERGETYCZNE, WAMPIRY] Wampiry energetyczne: symptomy, ochrona.

Pobrano z:

https://www.youtube.com/watch?v=8ICuzl4saEQ\&list=PLgmx6UvaMLHk5tIDvmFL0 PfUPjp-sRT7Y\&index=18

Allthingsparanormal

Inorganic Beings - Emotional Energy Vampires. Pobrano z:

https://www.youtube.com/watch?v=gEAX88umMa0\&list=PLgmx6UvaMLHmpnMG7

Av0rJv07I_gfRziL\&index $=30$

aron jasnowidz 1

DIAGNOZOWANIE LUDZI - WAMPIRY ENERGETYCZNE -CIEMNA ENERGIA W

PRZESTRZENI. Pobrano z:

https://www.youtube.com/watch?v=PrH8XyzPDWQ\&list=PLgmx6UvaMLHk5tIDvmF LOPfUPjp-sRT7Y\&index=19

aron jasnowidz 2

WAMPIR ENERGETYCZNY JAK PRZESTAĆ NIM BYĆ ,DUSZE Z MROKU. Pobrano

https://www.youtube.com/watch?v=Dk2r0IdIPwo\&list=PLgmx6UvaMLHk5tIDvmFL0 PfUPjp-sRT7Y\&index $=20$

ARTUVIA Oczyszczanie energetyczne

Wampiryzm energetyczny. Pobrano z:

https://www.youtube.com/watch?v=Zp6KdJXcJR8\&index=24\&list=PLgmx6UvaMLH k5tIDvmFL0PfUPjp-sRT7Y

Ashera Star Goddess

Psychic Vampirism How to Harness Energy. Pobrano z:

https://www.youtube.com/watch?v=kPVeBPQcwvk\&list=PLgmx6UvaMLHmpnMG7

Av0rJv07I_gfRziL\&index=17

Czarownica Joanna Wiśniewska 1

${ }^{3}$ Spis źródeł uporządkowany jest alfabetycznie według nazw kanałów, na których je opublikowano $\mathrm{W}$ tytułach filmów zachowano oryginalną ortografię i interpunkcję. 
wampiry energetyczne co to jest jak sobie radzić. Pobrano z:

https://www.youtube.com/watch?v=aQ7Dob6sUrg\&list=PLgmx6UvaMLHk5tIDvmFL 0PfUPjp-sRT7Y\&index $=28$

Czarownica Joanna Wiśniewska 2

rytuat odcięcia od wampirów energetycznych. Pobrano z:

https://www.youtube.com/watch?v=BiB1rzDs0Pk\&index=29\&list=PLgmx6UvaMLHk 5tIDvmFL0PfUPjp-sRT7Y

Czarownica Joanna Wiśniewska 3

Wampiry Energetyczne. Pobrano z: https://www.youtube.com/watch?v=e-cekfdx-

ZQ\&index=2\&list=PLgmx6UvaMLHk5tIDvmFL0PfUPjp-sRT7Y

DandapaniLLC

Don't feel guilty about NOT spending time with energy vampires. Pobrano z: https://www.youtube.com/watch?v=nsrkPNbAzCg\&list=PLgmx6UvaMLHmpnMG7A v0rJv07I_gfRziL\&index=2

Divine White Light

Reiki To Stop Energy Vampires | Energy Healing | Emotional \& Psychic Vampires.

Pobrano z: https://www.youtube.com/watch?v=e-

dpftWduvE\&index=28\&list=PLgmx6UvaMLHmpnMG7Av0rJv07I_gfRziL

Edek z Krainy Kredek

Wampiry energetyczne i negatywna energia. Pobrano z:

https://www.youtube.com/watch?v=NAKYOQq8qJ8\&list=PLgmx6UvaMLHk5tIDvmF L0PfUPjp-sRT7Y\&index $=26$

Entrepreneurs in Cars

Energy Vampires \& Why You Should Get Rid of Them. Pobrano z:

https://www.youtube.com/watch?v=SwY1hb1Q6Ms\&index=26\&list=PLgmx6UvaML

HmpnMG7Av0rJv07I_gfRziL

Evan Brand

Energy Vampires: Signs, Symptoms and What You Can Do About Them. Pobrano z: https://www.youtube.com/watch?v=kZ-

JAV6rWiE\&index=14\&list=PLgmx6UvaMLHmpnMG7Av0rJv07I_gfRziL

Grace Carter

Energetyczne Wampiry i ich wplyw na Nas. Pobrano z: https://www.youtube.com/watch?v=04WW_5qMEPs\&list=PLgmx6UvaMLHk5tIDvm FLOPfUPjp-sRT7Y\&index $=9$

HowStuffWorks

Stuff They Don't Want You To Know - Energy Vampires. Pobrano z:

https://www.youtube.com/watch?v=dVQ-

cBcTPro\&index=8\&list=PLgmx6UvaMLHmpnMG7Av0rJv07I_gfRziL

Infinite Waters (Diving Deep) 1

5 Signs Someone Is An Energy Vampire. Pobrano z:

https://www.youtube.com/watch?v=c6z5nEToPyU\&index=3\&list=PLgmx6UvaMLHm pnMG7Av0rJv07I_gfRziL

Infinite Waters (Diving Deep) 2 
Psychic Vampires (How to Spot and Protect Yourself From an Energy Vampire). Pobrano z: https://www.youtube.com/watch?v=padUrRKT_s\&index=5\&list=PLgmx6UvaMLHmpnMG7Av0rJv07I_gfRziL

Infinite Waters (Diving Deep) 3

How to Stop Energy VAMPIRES. Pobrano z: https://www.youtube.com/watch?v=Noym-keqZc\&list=PLgmx6UvaMLHmpnMG7Av0rJv07I_gfRziL\&index=25

Inne Medium

Jak rozpoznać wampira energetycznego ? Pobrano z:

https://www.youtube.com/watch?v=v1Nzadrm1oU\&index=1\&list=PLgmx6UvaMLHk 5tIDvmFL0PfUPjp-sRT7Y

Jakub Ławniczak

Jak wampiry emocjonalne odbudowuja siebie po nieudanych relacjach. Pobrano z: https://www.youtube.com/watch?v=pp0Tn_HvOwA\&index=21\&list=PLgmx6UvaML Hk5tIDvmFLOPfUPjp-sRT7Y

Jasnowidz Vanessa 1

Wampiry energetyczne (ochrona) - Jasnowidz Vanessa. Pobrano z:

https://www.youtube.com/watch?v=X0CYEPQSlwA\&index=13\&list=PLgmx6UvaML Hk5tIDvmFL0PfUPjp-sRT7Y

Jasnowidz Vanessa 2

"Wampiry emocjonalne", Jak się ochronić przed osobami przebywającymi razem z nami pod jednym dachem? Pobrano z:

https://www.youtube.com/watch?v=DrhAB86xkQA\&list=PLgmx6UvaMLHk5tIDvmF LOPfUPjp-sRT7Y\&index $=14$

Jasnowidz Vanessa 3

Jak obronić się przed wampirem energetycznym? „Ksiażka o wampirach”, czy warto być ,wampirem"? Pobrano z:

https://www.youtube.com/watch?v=VQ1WGaphLJc\&list=PLgmx6UvaMLHk5tIDvmF L0PfUPjp-sRT7Y\&index $=15$

Jasnowidz Vanessa 4

„wampiry energii”, czy warto być „,wampirem”? Dlaczego nie warto być wampirem energetycznym? Pobrano $\mathrm{z}$ : https://www.youtube.com/watch?v=AZ8Cw2LNGo\&list=PLgmx6UvaMLHk5tIDvmFL0PfUPjp-sRT7Y\&index=16

Josie Grouse

5 Signs Your Friend is an "Energy Vampire". Pobrano z:

https://www.youtube.com/watch?v=qCVGQ0kr2h0\&index=15\&list=PLgmx6UvaMLH mpnMG7Av0rJv07I_gfRziL

judithorloffmd

How To Spot Energy Vampires. Pobrano z: https://www.youtube.com/watch?v=XqYWslvqnKU\&index=10\&list=PLgmx6UvaML HmpnMG7Av0rJv07I_gfRziL

LifeScriptDoctor 
Psychic Attack Defense | Energy Vampire Protection Technique. Pobrano z: https://www.youtube.com/watch?v=zJZfREfzP6I\&list=PLgmx6UvaMLHmpnMG7Av0 rJv07I_gfRziL\&index $=7$

Lyra Scotch

How To Tell If You Are An Energy Vampire. Pobrano z:

https://www.youtube.com/watch?v=T8yBS1Dj1DE\&list=PLgmx6UvaMLHmpnMG7A v0rJv07I_gfRziL\&index $=6$

Maria Bucardi 1

Wampiryzm wampiry utrata energii i jak się bronić oraz turmalin Schörl - Maria

Bucardi rytuaty. Pobrano z:

https://www.youtube.com/watch?v=prQu1BkwrYM\&index=10\&list=PLgmx6UvaML Hk5tIDvmFL0PfUPjp-sRT7Y

Maria Bucardi 2

Mój mąż lub żona jest wampirem energetycznym Toksyczni ludzie, wampiryzm spotkanie z Maria Bucardi. Pobrano z:

https://www.youtube.com/watch?v=e3BwgDQeq0A\&list=PLgmx6UvaMLHk5tIDvmF LOPfUPjp-sRT7Y\&index $=11$

Matthew Rosenberg

The Truth about Energy Vampires: Empaths. Pobrano z:

https://www.youtube.com/watch? v=w7zkFsrW-

xg\&list=PLgmx6UvaMLHmpnMG7Av0rJv07I_gfRziL\&index=20

NinjightNationCorp

Energy Vampires are REAL. Pobrano z:

https://www.youtube.com/watch?v=Ek5xRkcdBS8\&list=PLgmx6UvaMLHmpnMG7A

v0rJv07I_gfRziL\&index=21

$\mathrm{Nu}$ Rebel Entertainment

ENERGY VAMPIRES. Pobrano z:

https://www.youtube.com/watch? $\mathrm{v}=8 \mathrm{uLIqkj} 3$ Vao\&index=9\&list=PLgmx6UvaMLHmp nMG7Av0rJv07I_gfRziL

Oshun Auset Maat

Are you a victim of energy vampires? Pobrano z:

https://www.youtube.com/watch?v=KXRFXuc96og\&index=23\&list=PLgmx6UvaMLH mpnMG7Av0rJv07I_gfRziL

ozzy1333

wampiry emocjonalne 20 . Pobrano z:

https://www.youtube.com/watch?v=vZWuTNnaabM\&list=PLgmx6UvaMLHk5tIDvmF LOPfUPjp-sRT7Y\&index $=23$

Polish Spiritual Coach 1

Nieświadome wampiry energetyczne. Pobrano z:

https://www.youtube.com/watch?v=YkBYe9BPw94\&list=PLgmx6UvaMLHk5tIDvmF LOPfUPjp-sRT7Y\&index=27

Polish Spiritual Coach 2 
Seksualny wampiryzm energetyczny. Pobrano z:

https://www.youtube.com/watch?v=YYcbGWww-

IE\&index=30\&list=PLgmx6UvaMLHk5tIDvmFL0PfUPjp-sRT7Y

Polish Spiritual Coach 3

Usuwanie / uwalnianie od podpięć, wampirów energetycznych, chipów - medytacja $i$ afirmacja. Pobrano z:

https://www.youtube.com/watch?v=dwc91GnEqo8\&list=PLgmx6UvaMLHk5tIDvmFL OPfUPjp-sRT7Y\&index=31

Polish Spiritual Coach 4

Zabezpieczenia energetyczne, byty, wampiry, ochrona, promieniowania. Pobrano z:

https://www.youtube.com/watch?v=k-

mf6dhxDTU\&index=12\&list=PLgmx6UvaMLHk5tIDvmFL0PfUPjp-sRT7Y

ProgreSówka

Ludzie, na których warto uważać - Wampiry energetyczne. (+ Ćwiczenie). Pobrano z: https://www.youtube.com/watch?v=W1wsfenfdEA\&list=PLgmx6UvaMLHk5tIDvmFL OPfUPjp-sRT7Y\&index=6

Rafał Dudek

Wampir Energetyczny - jak się bronić i uodpornić na narzekajacych ludzi? Pobrano z: https://www.youtube.com/watch?v=HwoQCbYKXSg\&index=8\&list=PLgmx6UvaML Hk5tIDvmFL0PfUPjp-sRT7Y

Rene Bastarache

7 Types of Energy Vampires and How-To Slay Them :-). Pobrano z: https://www.youtube.com/watch? $\mathrm{v}=1 \mathrm{Cc} 5$ wucgsys\&index=13\&list=PLgmx6UvaMLHm pnMG7Av0rJv07I_gfRziL

Reprogram The Matrix

Energy Vampire Lesson. Pobrano z:

https://www.youtube.com/watch?v=6ZGjzoRSMng\&list=PLgmx6UvaMLHmpnMG7A v0rJv07I_gfRziL\&index $=16$

Robert Marchel

Wampiry energetyczne. Jak sobie z nimi radzić? Pobrano z:

https://www.youtube.com/watch?v=HhMBA3Sw8TU\&list=PLgmx6UvaMLHk5tIDvm FLOPfUPjp-sRT7Y\&index=7

Scott Bolan

How to Stop Energy Vampires. Pobrano z:

https://www.youtube.com/watch?v=SX3uFN_LQnU\&list=PLgmx6UvaMLHmpnMG7

Av0rJv07I_gfRziL\&index $=18$

Siim Land

Energy Vampires and Things That Drain Your Energy. Pobrano z: https://www.youtube.com/watch?v=3gnI1quLwdI\&index=19\&list=PLgmx6UvaMLHm pnMG7Av0rJv07I_gfRziL

Spiritual Awakening

Spiritual Protection: From Energy Vampires, Negative Entities \& Bad Energies.

Pobrano z: 
https://www.youtube.com/watch?v=UHvpBHt4vGc\&list=PLgmx6UvaMLHmpnMG7A v0rJv07I_gfRziL\&index=24

SpiritualThoughts

Energy Vampires // SpiritualThoughts. Pobrano z:

https://www.youtube.com/watch?v=778UnzKh1Xg\&list=PLgmx6UvaMLHmpnMG7A v0rJv07I_gfRziL\&index $=27$

Szkoła Kosmoenergetyki

Wampiryzm energetyczny. Pobrano z: https://www.youtube.com/watch?v=7G-

LpHN2OlA\&list=PLgmx6UvaMLHk5tIDvmFL0PfUPjp-sRT7Y\&index=22

Teal Swan

Psychic Vampires (How to Recognize and Protect Yourself From an Energy Vampire) -

Teal Swan. Pobrano z: https://www.youtube.com/watch?v=FWM-

92ripck\&index=4\&list=PLgmx6UvaMLHmpnMG7Av0rJv07I_gfRziL

Tobias Lars

Psychic Vampires \& Spiritual Energy Vampires - How to stay Immune. Pobrano z: https://www.youtube.com/watch? $\mathrm{v}=$ ChjyzpgoTtA\&list=PLgmx6UvaMLHmpnMG7Av 0rJv07I_gfRziL\&index $=12$

Universal Frequencies

Identifying Energy Vampires And Psychic Attacks /Prevention And Protection For Yourself Part 1. Pobrano z:

https://www.youtube.com/watch?v=DPzqhwHiryI\&list=PLgmx6UvaMLHmpnMG7Av 0rJv07I_gfRziL\&index $=22$

Victoria Donahue

How to Spot an Energy Vampire \& 4 Tips for Dealing with Them. Pobrano z:

https://www.youtube.com/watch?v=j2BwITRuLhY\&index=1\&list=PLgmx6UvaMLH mpnMG7Av0rJv07I_gfRziL

Wiedźma Malwina Mallefica 1

WAMPIRYZM ENERGETYCZNY - czym jest? na czym polega? Pobrano z:

https://www.youtube.com/watch?v=JtxOrhyKzAY\&list=PLgmx6UvaMLHk5tIDvmFL OPfUPjp-sRT7Y\&index=3

Wiedźma Malwina Mallefica 2

Jak rozpoznać wampiryzm energetyczny i jak się bronić. Pobrano z:

https://www.youtube.com/watch?v=WVKPB6_draI\&list=PLgmx6UvaMLHk5tIDvmF LOPfUPjp-sRT7Y\&index $=4$

YOGA de la VIDA Greg 1

Wampiry energetyczne - zabieranie nam naszej energi \#273. Pobrano z:

https://www.youtube.com/watch?v=akS2Ff_QUaU\&list=PLgmx6UvaMLHk5tIDvmFL OPfUPjp-sRT7Y\&index=5

YOGA de la VIDA Greg 2

Podczepy demonów $w$ ciele człowieka \#552. Pobrano z:

https://www.youtube.com/watch?v=iuj3_tNWV8E\&list=PLgmx6UvaMLHk5tIDvmFL

0PfUPjp-sRT7Y\&index $=25$ 


\section{Opracowania}

BARTMIŃSKI, J. (1990). Folklor, język, poetyka. Wrocław: Zakład Narodowy im. Ossolińskich.

CHESS, S., Newsom, E. (2015). Folklore, Horror Stories, and the Slender Man: The Development of an Internet Mythology. New York: Macmillan.

DunDES, A. (1977). Literatura oralna (przeł. J. Banach). „Literatura Ludowa”, 21 (4/5), 99-107.

GAJ-PIOTROWSKI, W. (1993). Duchy i demony w wierzeniach ludowych z okolic Stalowej Woli, Rozwadowa i Tarnobrzega. Wrocław: Polskie Towarzystwo Ludoznawcze.

GIDDENS, A. (2010). Nowoczesność i tożsamość: „Ja” i spoleczeństwo w epoce późnej nowoczesności (przeł. A. Szulżycka). Warszawa: Wydawnictwo Naukowe PWN.

GROCHOWSKI, P. (2013). Folklorysta w sieci: Prolegomena do badań folkloru internetowego. W: P. Grochowski (red.), Netlor. Wiedza cyfrowych tubylców. Torun: Wydawnictwo Naukowe UMK.

GROCHOWSKI, P. (2016). Zmora w internecie: O statusie współczesnych wyobrażeń demonicznych. „Literatura Ludowa”, 60 (3), 37-52. doi 10.12775/LL.3.2016.004.

GROCHOWSKI, P. (2017). Od strzygoni do wampirów energetycznych: Folklor jako system praktyk interpretacyjnych. „Przegląd Kulturoznawczy”, 32 (2), 223-242. doi: 10.4467/20843860PK.17.015.7363

HAJDUK-NiJAKOWSKA, J. (2016). Doświadczanie pamięci: Folklorystyczny kontekst opowieści wspomnieniowych. Opole: Wydawnictwo Uniwersytetu Opolskiego.

KADŁUBIEC, D. (1999). Między memoratem a fabulatem. W: T. Smolińska (red.), Folklorystyczne i antropologiczne opisanie świata: Ksiega ofiarowana profesor Dorocie Simonides. Opole: Uniwersytet Opolski.

KOWALSKI, P. (1990). Współczesny folklor i folklorystyka: O przedmiocie poznania $w$ dzisiejszych badaniach folklorystycznych. Wrocław : Polskie Towarzystwo Ludoznawcze.

MATHEWS, G. (2005). Supermarket kultury: Kultura globalna a tożsamość jednostki (przeł. E. Klekot). Warszawa: Państwowy Instytut Wydawniczy.

SIMONIDES, D. (1981). Memorat i fabulat we współczesnej folklorystyce. W: W. Nawrocki, M. Waliński (red.), Literatura popularna - folklor - język. Katowice: Uniwersytet Śląski. 


\section{PIOTR GROCHOWSKI}

\section{ANTI-VAMPIRE Tutorials ON YouTube: Between ExPERT Discourse AND CYBERFOLKLORE}

The article presents the results of the research on films about energy vampirism published on YouTube. The main objective of this research was to establish the status of knowledge generated and disseminated via anti-vampire tutorials. The analysis of the video clips, the specificity of the channels where they were published, and the viewers' commentaries beneath them show that this knowledge of dual and paradoxical nature. On the one hand, it presented as expert and professional in that it is created by exceptional individuals on the basis of their own studies and experiences. On the other hand, it is also a form of folklore, which means that it involves the transmission of standardized views and ideas commonly shared within a given group of people. Hence it contributes to the integrity of this group and facilitates identification and identity-making processes. It also stimulates joint actions. 